Shamik Bhattacharyya, MD

Janice C. Wong, MD

Malak Abedalthagafi, MD

Sarah Wahlster, MD

Henrikas Vaitkevicius, MD

Neurol Neuroimmunol Neuroinflamm

2015;2:e90; doi: 10.1212/ NXI.0000000000000090

\section{MYELODYSPLASTIC SYNDROME WITH PROGRESSIVE MULTIFOCAL PREDOMINANTLY PONTINE DEMYELINATION \\ OPEN}

We report a patient with fulminant brainstem demyelinating disease in the context of previously treated myelodysplastic syndrome (MDS). We hypothesize that autoimmunity associated with MDS can underlie demyelinating syndromes.

Clinical case. A 64-year-old man with relapsing polychondritis in remission and stable MDS (diagnosed 1.5 years ago, maintained on $5 \mathrm{mg}$ of oral prednisone with anemia, lymphopenia [140 lymphocytes/ $\mu \mathrm{L}]$, and mild thrombocytopenia $[140,000$ platelets/ $\mu L])$ without history of opportunistic infections was hospitalized after 1 day of difficulty walking. On the first day of hospitalization, he developed dysarthria, bilateral sixth cranial nerve deficits, and bilateral dysmetria. MRI of the brain showed T2 hyperintensities involving the pons and midbrain along with discrete right temporal, right frontal, and left parietal lesions (figure, A-C). All lesions enhanced with IV gadolinium contrast. CSF contained 10 white blood cells per $\mu \mathrm{L} \quad(40 \%$ lymphocytes), no red blood cells, glucose $45 \mathrm{mg} / \mathrm{dL}$, and total protein $77 \mathrm{mg} / \mathrm{dL}$. Five days after symptom onset, he progressed to no voluntary extraocular movements and decreased arousal. He was treated with broad-spectrum antimicrobials including acyclovir and ampicillin as well as 5-day pulse of methylprednisolone.

Despite these therapies, he became increasingly somnolent and was found to have further expansion of the brainstem and right temporal lesions on imaging. CSF studies were negative for infectious organisms (including serology for West Nile virus, eastern equine encephalitis virus, and varicella-zoster virus; and PCR for herpes simplex virus [HSV], JC virus, and enterovirus). Oligoclonal bands were absent, as were anti-Ri, anti-Hu, and anti-amphiphysin antibodies. Serum neuromyelitis optica (NMO) IgG tested by cell-binding assay was negative. The right temporal lesion was biopsied. Histology showed a sharply circumscribed demyelinating lesion with foamy macrophages (myelin stain, figure, D; broken arrow, figure, E) and relative preservation of axons (Bodian stains; not shown). No perivascular lymphocytes - which would be expected in acute disseminated encephalomyelitis (ADEM) — were seen. Lymphocytes were predominantly $\mathrm{T}$ cells with virtually no B cells (CD3 and CD20 immunostains; data not shown). There was acute hemorrhage throughout the lesion (solid arrow, figure, E). No viropathic changes or neuronal inclusions were seen. Immunohistochemistry for simian virus 40, HSV, cytomegalovirus, and Epstein-Barr virus antigens was negative. Immediately after the biopsy, the patient became comatose with extensor posturing in bilateral upper extremities. Repeat MRI of the brain showed marked extension of the T2 hyperintensity into superior midbrain and thalami (figure, F). He sequentially received high-dose methylprednisolone, IV immunoglobulin, and induction cyclophosphamide. His mental status, however, did not significantly improve. He died 8 weeks after onset of illness after the family withdrew positive pressure ventilation.

Discussion. This patient had a fulminant demyelinating disease of unclear etiology. Histologically, the circumscribed region of confluent demyelination is most consistent with a multiple sclerosis (MS) plaque, although the patient's relentlessly progressive course is atypical of relapsing-remitting MS and more suggestive clinically of the Marburg subtype. ${ }^{1,2}$ Histologically, the demyelinating lesion is not characteristic of ADEM, which is marked by perivenular inflammation and demyelination. ${ }^{2} \mathrm{NMO}$ is unlikely in this patient due to the lack of myelopathy, optic nerve involvement, suggestive pathology, and NMO antibody. ${ }^{3}$ The recently described CLIPPERS (chronic lymphocytic inflammation with pontine perivascular enhancement responsive to steroids) syndrome is associated with prominent brainstem involvement but also with perivascular lymphocytic infiltrate not seen in this patient. ${ }^{4}$ Central pontine myelinolysis can cause a similar syndrome with brainstem dysfunction; however, the patient did not have the fluctuations in sodium levels that usually precede pontine myelinolysis.

MDS, on the other hand, has associated autoimmunity in about $10 \%$ of patients. ${ }^{5,6}$ A variety of autoimmune diseases can occur with MDS, including both acute syndromes such as vasculitic glomerulonephritis and chronic diseases such as pulmonary fibrosis or Sjögren syndrome. ${ }^{6}$ Autoimmunity can precede, present concurrently with, or follow the diagnosis of MDS. ${ }^{6}$ Cytokine dysregulation in the 

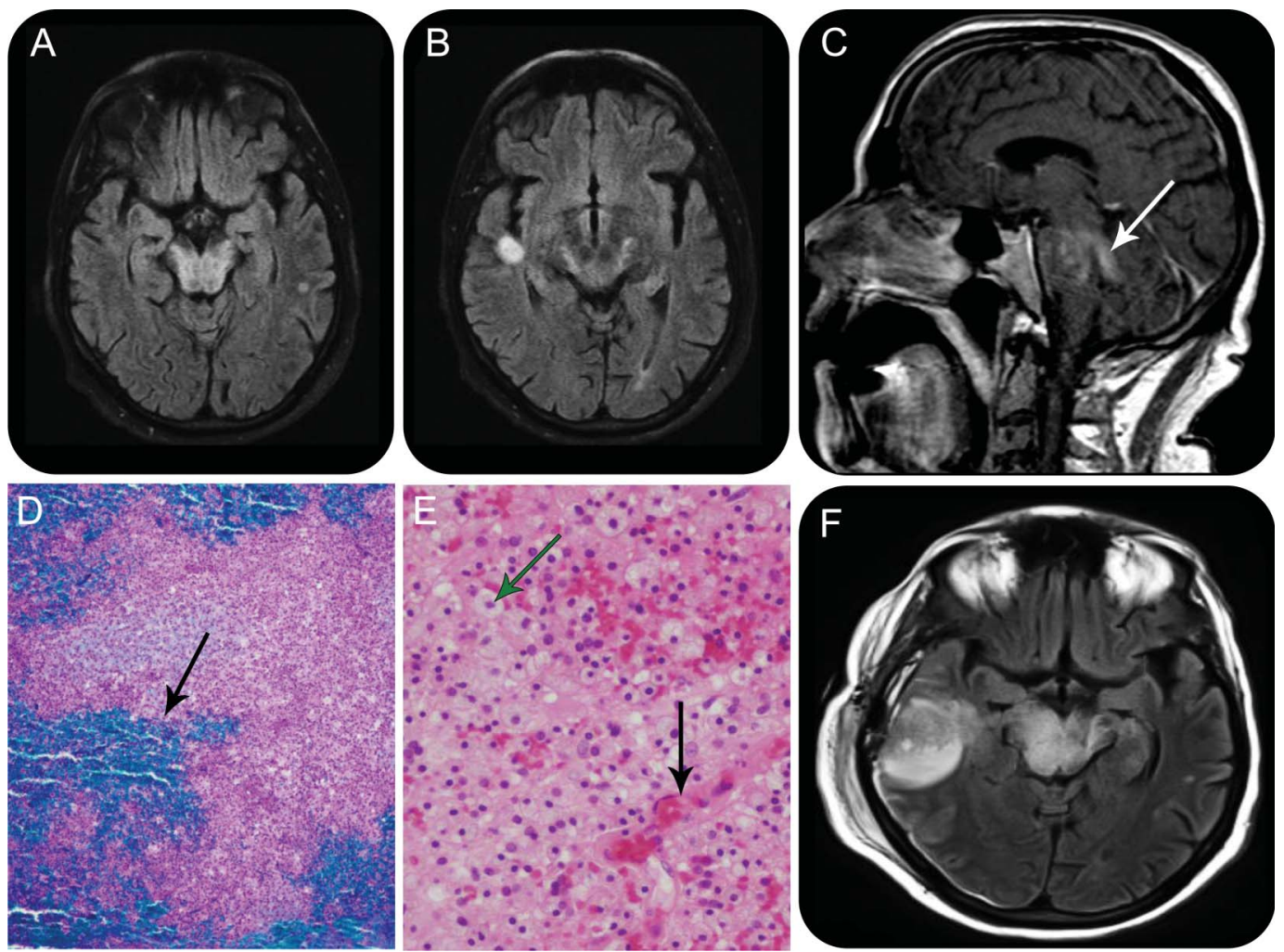

(A) Symmetric T2 hyperintensity in the midbrain with relative sparing of cerebral peduncles. (B) Discrete T2-hyperintense lesion (biopsied subsequently) in the right temporal lobe. (C) T1 postcontrast image (arrow) showing enhancement of brainstem lesions. (D) The right temporal lesion is relatively sharply circumscribed and devoid of myelin (arrow), Luxol fast blue (myelin stain), 200×. (E) The lesion consists of large numbers of foamy macrophages (green arrow) and acute intraparenchymal hemorrhages (black arrow), hematoxylin and eosin stain, 400×. (F) Enlarging T2-hyperintense lesions in the midbrain and right temporal lobe immediately after biopsy.

bone marrow secondary to transformed hematopoietic progenitor cell proliferation is hypothesized to lead to chronic immune activation resulting in autoimmunity. ${ }^{5}$ While the causality of MDS in our patient's disease is uncertain, the development of 2 autoimmune disorders (relapsing polychondritis and demyelinating syndrome) following diagnosis of MDS is suggestive of the etiologic role of MDS for these autoimmune disorders. There is one prior report of steroid-responsive recurrent tumefactive frontal and parietal demyelinating lesions in a 70-year-old man preceding diagnoses of MDS and renal cell carcinoma. ${ }^{7}$ We present a case of rapidly progressive refractory CNS demyelinating disease associated with MDS. In our patient, the CNS demyelinating disease worsened dramatically after the biopsy. While the biopsy and worsening course of disease may have been coincident, we hypothesize that the demyelinating disorder was antibodymediated and that the breakdown of the bloodbrain barrier from the biopsy exacerbated the disease.

In summary, we propose that MDS may lead to demyelinating disease, which can be fulminant. Recognition of this association clinically may prompt consideration of early aggressive immune modulation therapy. Further epidemiologic research to investigate the association between MDS and demyelinating syndromes is needed.

From the Department of Neurology (S.B., J.C.W., S.W.), Massachusetts General Hospital, Boston, MA; Department of Neurology (S.B., J.C.W., S.W., H.V.) and Department of Pathology (M.A.), Brigham and Women's Hospital, Boston, MA; and Harvard Medical School (S.B., J.C.W., M.A., S.W., H.V.), Boston, MA.

Author contributions: Drs. Bhattacharyya, Wong, Abedalthagafi, Wablster, and Vaitkevicius all participated in the conception and writing of the article.

Study funding: No targeted funding reported.

Disclosure: The authors report no disclosures. Go to Neurology.org/nn for full disclosure forms. The Article Processing Charge was paid by the authors.

This is an open access article distributed under the terms of the Creative Commons Attribution-Noncommercial No Derivative 3.0 License, which permits downloading and sharing the work provided it is properly cited. The work cannot be changed in any way or used commercially.

Received November 7, 2014. Accepted in final form January 29, 2015.

Correspondence to Dr. Bhattacharyya: sbhattacharyya3@partners.org

1. Lucchinetti C, Brück W, Parisi J, Scheithauer B, Rodriguez M, Lassman H. Heterogeneity of multiple sclerosis lesions: implications for the pathogenesis of demyelination. Ann Neurol 2000;47:707-717. 
2. Young NP, Weinshenker BG, Lucchinetti CF. Acute disseminated encephalomyelitis: current understanding and controversies. Semin Neurol 2008;28:84-94.

3. Wingerchuk DM, Lennon VA, Lucchinetti CF, Pittock SJ, Weinshenker BG. The spectrum of neuromyelitis optica. Lancet Neurol 2007;6:805-815.

4. Pittock SJ, Debruyne J, Krecke KN, et al. Chronic lymphocytic inflammation with pontine perivascular enhancement responsive to steroids (CLIPPERS). Brain 2010;133: 2626-2634.
5. Voulgarelis M, Giannouli S, Ritis K, Tzioufas AG. Myelodysplasia-associated autoimmunity: clinical and pathophysiologic concepts. Eur J Clin Invest 2004;34:690-700.

6. Castro M, Conn DL, Su WP, Garton JP. Rheumatic manifestations in myelodysplastic syndromes. J Rheumatol 1991;18:721-727.

7. Häne A, Bargetzi M, Hewer E, Bruehlmeier M, Khamis A, Roelcke U. Recurrent tumefactive demyelination without evidence of multiple sclerosis or brain tumour. J Neurol 2011;258:318-320. 


\section{Neurology \\ Neuroimmunology \& Neuroinflammation}

\section{Myelodysplastic syndrome with progressive multifocal predominantly pontine demyelination}

Shamik Bhattacharyya, Janice C. Wong, Malak Abedalthagafi, et al.

Neurol Neuroimmunol Neuroinflamm 2015;2;

DOI 10.1212/NXI.0000000000000090

This information is current as of March 12, 2015

Updated Information \&

Services

References

Subspecialty Collections

Permissions \& Licensing

Reprints including high resolution figures, can be found at:

http://nn.neurology.org/content/2/3/e90.full.html

This article cites 7 articles, 0 of which you can access for free at: http://nn.neurology.org/content/2/3/e90.full.html\#\#ref-list-1

This article, along with others on similar topics, appears in the following collection(s):

All Demyelinating disease (CNS)

http://nn.neurology.org//cgi/collection/all_demyelinating_disease_cns

Autoimmune diseases

http://nn.neurology.org//cgi/collection/autoimmune_diseases

Hematologic

http://nn.neurology.org//cgi/collection/hematologic

MRI

http://nn.neurology.org//cgi/collection/mri

Information about reproducing this article in parts (figures,tables) or in its entirety can be found online at:

http://nn.neurology.org/misc/about.xhtml\#permissions

Information about ordering reprints can be found online:

http://nn.neurology.org/misc/addir.xhtml\#reprintsus

Neurol Neuroimmunol Neuroinflamm is an official journal of the American Academy of Neurology.

Published since April 2014, it is an open-access, online-only, continuous publication journal. Copyright $(\subseteq$ 2015 American Academy of Neurology. All rights reserved. Online ISSN: 2332-7812.

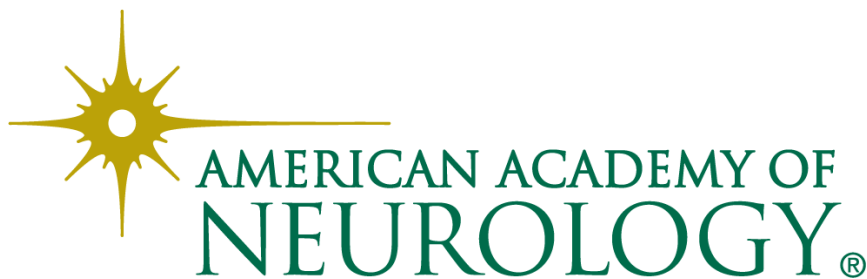

